\title{
Lost To Follow-Up
}

National Cancer Institute

\section{Source}

National Cancer Institute. Lost To Follow-Up. NCI Thesaurus. Code C48227.

The loss or lack of continuation of subject participation after a study has officially closed. 